\title{
Pengaruh Konseling Rational Emotif Behavioral Therapy (REBT) dalam Mengurangi Kecemasan Peserta Didik Kelas VIII SMP Gajah Mada Bandar Lampung
}

\author{
Andi Thahir, Dede Rizkiyani
}

Dosen Fakultas Tarbiyah dan Keguruan, IAIN Raden Intan Lampung

Diterima: 28 April 2016. Disetujui: 20 Juni 2016. Dipublikasikan: Agustusl 2016

\begin{abstract}
Abstrak: Tujuan yang ingin dicapai dalam penelitian ini untuk mengetahui gambaran sebelum dan sesudah diberikan perlakuan dan mengetahui apakah konseling Rational Emotif Behavioral Therapy (REBT) dapat mengurangi kecemasan peserta didik di SMP Gajah Mada Bandar Lampung. Jenis penelitian ini adalah penelitian kuantitatif pre- Experimental designs. Peneliti menggunakan One-Group Pretest-Posttest Designs. Sampel dari penelitian ini adalah 19 peserta didik yang berasal dari kelas VIII SMP Gajah Mada Bandar Lampung. Pemilihan sampel peneliti menggunakan sampling purposive yaitu tekik penentuan sampel dengan pertimbangan tertentu. Hasil penelitian dapat disimpulkan bahwa rational emotif behavioral therapy (REBT) memiliki pengaruh dalam mengurangi kecemasan peserta didik di SMP Gajah Mada Bandar Lampung.
\end{abstract}

Kata kunci: Rational Emotif Behavioral Therapy (REBT); Kecemasan, Konseling Kelompok

\section{Pendahuluan}

Pelayanan konseling kelompok yaitu layanan bimbingan dan konseling yang memungkinkan peserta didik memperoleh kesempatan untuk pembahasan dan pengentasan permasalahan yang dialaminya melalui dinamika kelompok. Gadza, dkk menyatakan bahwa layanan konseling kelompok adalah suatu proses antara pribadi yang terpusat pada pribadi yang dinamis, terpusat pada pemikiran dan perilaku yang sadar dan melibatkan fungsi-fungsi seperti berorientasi pada kenyataan, saling mempercayai, saling pengertian, saling menerima, dan saling mendukung. Selanjutnya Nurihsan mengemukakan bahwa konseling kelompok adalah suatu upaya bantuan kepada peserta didik dalam suasana kelompok yang bersifat pencegahan dan penyembuhan, dan diarahkan kepada pemberian kemudahan dalam rangka perkembangan dan pertumbuhannya.

Berdasarkan beberapa pengertian dari konseling kelompok dapat disimpulkan bahwa konseling kelompok ialah suatu proses bantuan yang diselesaikan secara kelompok. Layanan konseling kelompok memiliki tujuan seperti halnya layanan bimbingan dan konseling yang lainnya, sebagai berikut: (a) melatih anggota kelompok agar berani berbicara dengan banyak orang; (b) melatih anggota kelompok dapat bertenggang rasa terhadap teman sebayanya; (c) dapat mengembangkan bakat dan minat masing- masing anggota kelompok; dan (d) Mengentaskan permasalahan-permasalahan kelompok.

Teknik Layanan Konseling Kelompok menurut Tohirin dalam Mardia bin Smith pelaksanaan konseling kelompok terdapat dua teknik, yaitu:

\section{a. Teknik Umum}

Teknik-teknik yang digunakan dalam penyelenggaraan layanan konseling kelompok mengacu pada berkembanganya dinamika kelompok yang diakui oleh seluruh anggota kelompok untuk mencapai tujuan layanan. Adapun teknik-teknik tersebut secara garis baris meliputi :

1) komunikasi multi arah secara efektif dan terbuka;

2) pemberian rangsangan untuk menimbulkan inisiatif dalam pembahasan, diskusi, analisis, dan pengembangan argumentasi

3) dorongan minimal untuk memantapkan respon aktivitas kelompok

4) penjelasan, pendalaman, pemberian contoh untuk memantapkan analisis, argumentasi dan pembahasan

5) pelatihan untuk membentuk pola tingkah laku yang dikehendaki. 
b. Teknik permainan kelompok

Yaitu dalam layanan konseling kelompok dapat diterapkan teknik permainan baik sebagai wahana (mediia) yang memuat materi pembinaan tertentu.

Freud (ahli psikoanalisis) menjelaskan bahwa kecemasan adalah reaksi terhadap ancaman dari rasa sakit maupun dunia luar yang tidak ditanggulangi dan berfungsi memperingatkan individu akan adanya bahaya. Calhoun dan Acocella menambahkan kecemasan adalah perasaan ketakutan (baik realistis maupun tidak realistis) yang disertai dengan keadaan peningkatan reaksi kejiwaan. Rollo May yang melihat bahwa kecemasan dipicu oleh ancaman terhadap nilai eksistensi dasar manusia.

Dalam kamus istilah psikologi, Chaplin menyatakan kecemasan sebagai perasaan campuran berisi ketakutan dan keprihatinan mengenai rasa-rasa mendatang tanpa sebab khusus untuk ketakutan tersebut. Menurut Priest memahami kecemasan yaitu kecemasan atau perasaan cemas adalah suatu keadaan yang dialami ketika berpikir tentang sesuatu yang tidak menyenangkan terjadi. Secara umum dapat disimpulkan bahwa kecemasan ialah keadaan takut atau bingung yang intens sebagai hasil dari antisipasi kejadian yang mengancam atau menantang. Jadi dapat dipahami kecemasan merupakan suatu kondisi dimana seseorang merasa tegang, khawatir pada situasi yang mengancamnya baik secara realita atau secara tidak realita, biasanya ditunjukkan dengan ketakutan yang timbul tanpa sebab yang khusus. Sependapat dengan pernyataan Priest dalam mengemukakan tentang kecemasan, Atkinson mengemukakan bahwa kecemasan merupakan emosi yang tidak menyenangkan yang ditandai dengan gejala seperti kekhawatiran dan perasaan takut.

Sementara itu, Spielberger mengemukakan bahwa kecemasan dapat dibedakan menjadi atas dua bagian, yaitu :

a. Kecemasan sebagai suatu sifat (trait anxiety), ialah kecenderungan pada diri seseorang untuk merasa terancam oleh sejumlah kondisi yang sebenarnya tidak berbahaya.

b. Kecemasan sebagai suatu keadaan (state anxiety), dimana suatu keadaan atau kondisi emosional sementara pada diri seseorang yang ditandai dengan perasaan tegang dan kekhawatiran yang dihayati secara sadar serta bersifat subyektif, dan meningginya aktivitas sistem saraf otonom.

Nevid mengemukakan kecemasan adalah keadaan khawatir yang mengeluhkan sesuatu yang buruk akan segera terjadi. Santrock menambahkan bahwa kecemasan adalah sebuah perasaan yang tidak menyenangkan akan ketakutan atau kekhawatir yang tidak begitu jelas. Dari pengertian menurut para ahli maka kecemasan dapat disimuplkan bahwa sesuatu keadaan ketidaknyamanan terhadap sesuatu hal atau kondisi yang membuat dirinya merasa tegang.

Salah satu bentuk kecemasan yang sering terjadi adalah kecemasan dalam hal berkomunikasi. Pada dunia pendidikan berkomunikasi sangatlah penting guna untuk menunjang keberhasilan dalam proses pembelajaran maka dari itu peserta didik dituntut untuk mampu berbicara di depan kelas, bertanya kepada guru, mempresentasikan tugas. Pada penelitian ini peneliti akan menekankan pada kecemasan berbicara di depan umum.

Rahayu berpendapat bahwa peserta didik yang mengalami kecemasan berbicara di depan umum akan mengarahkan mereka untuk tidak

presentasi, menurunkan frekuensi dan intensitas keterlibatannya dalam transaksi berbicara di depan umum, sehingga dirinya akan menghindari situasi berbicara di depan umum. Berbicara di depan umum adalah suatu variasi atau perluasan percakapan, seorang pembicara menghadapi pendengar dalam jumlah

banyak yang bertujuan untuk mempublikasikan informasi dalam situasi tatap muka.

Menurut Monarth \& Kase, faktor- faktor yang mempengaruhi kecemasan berbicara di depan umum adalah, sebagai berikut: 
a. Faktor biologis

Pada saat menghadapi situasi yang membuatnya merasa tidak nyaman, respon fisiologis yang tampak ialah:

1) sistem saraf simpatis memproduksi dan melepaskan adrenalin yaitu suatu hormon fight (menghadapi) dan flight (menghindari) situasi bahaya.

2) detak jantung berdebar-debar, tekanan darah naik, wajah bersemu merah.

3) merasakan adanya sensasi dingin dan gemetar pada tangan dan kaki.

4) nafas memburu dengan cepat, mengalami sakit kepala ringan dan berkeringat sekujur tubuh.

b. Faktor pikiran negatif, pikiran negatif yang umumnya timbul ialah:

1) bahwa berbicara di depan umum menakutkan

2) adanya perasaan kurang mampu mengatasi beberapa kesulitan situasi.

c. Faktor perilaku menghindar

Ada beberapa perilaku yang muncul terkait dengan kondisi tersebut, yaitu:

1) Menghindari situasi yang menakutkan.

2) Perilaku cemas yaitu perilaku yang sering tampak dalam situasi berbicara di depan umum.

d. Faktor emosional

Dalam faktor emosional individu tersebut cenderung merasakan perasaan cemas, takut, kuatir, merasa tidak mudah menghadapi situasi, tegang, panik, dan gugup menghadapi situasi berbicara di depan umum.

Menurut Kartono membagi kecemasan menjadi dua jenis kecemasan, seperti (a) kecemasan ringan; dan (b) kecemasan berat. Adapun penjelasan masing-masing dari kecemasan tersebut, sebagai berikut:

a. Kecemasan ringan, kecemasan ringan dibagi menjadi dua kategori yaitu:

1) Kecemasan ringan yang muncul sebentar adalah suatu kecemasan yang wajar terjadi pada individu akibat situasi-situasi yang mengancam pada individu tersebut tidak dapat mengatasinya sehingga timbulnya kecemasan.

2) Kecemasan ringan yang lama adalah kecemasan yang dapat diatasi tetapi karena individu tersebut tidak segera mengatasi penyebab munculnya kecemasan, maka kecemasan tersebut akan mengendap lama dalam diri individu.

b. Kecemasan berat adalah kecemasan yang terlalu berat dan berakar secara mendalam dalam diri seseorang. Kecemasan berat dibagi menjadi dua kategori, yaitu :

1) Kecemasan berat yang sebentar dapat menimbulkan traumatis pada individu jika menghadapi situasi yang sama.

2) Kecemasan yang berat tetapi munculnya lama akan merusak kepribadian individu (Prambudhi Ambar Yuliastri dkk, 2015). Berdasarkan uraian yang telah dikemukakan, maka dapat ditarik kesimpulan bahwa jenis-jenis kecemasan ialah suatu kecemasan yang wajar terjadi pada individu akibat situasi yang mengancam dirinya serta dapat menimbulkan traumatis dan akan merusak kepribadian individu itu sendiri.

Dengan melihat dari beberapa paparan maka diperlukan suatu treatment yang dapat langsung menyentuh pada perilaku cemas yang dimunculkan. Salah satu treatment yang disarankan adalah Rational Emotif Behavior Therapy (REBT). Rational Emotif Behavior Therapy (REBT) merupakan suatu pendekatan yang berasumsi sebagai makhluk berpikir dan makhluk perasa, sedangkan perilakunya hanya sebatas simultan di antara keduanya, pikiran memperngaruhi perasaan dan pikiran.

Menurut George \& Cristiani Rational Emotif Behavior Therapy (REBT) adalah pendekatan bersifat direktif, yaitu pendekatan yang membelajarkan kembali konseli untuk memaham input kognitif yang menyebabkan gangguan emosional, mencoba mengubah pikiran 
konseli agar membiarkan pikiran irasionalnya atau belajar mengantisipasi manfaat atau konsekuensi dari tingkah laku.

Sedangkan menurut Albert Ellis REBT (Rational Emotif Behavior Therapy) adalah suatu rancangan terapeutik, dalam konseling atau psikoterap, pemakaian rancangan ini mementingkan berpikir irasional sebagai tujuan terapeutik, menekankan modifikasi atau pengubahan keyakinan irasional yang telah merupakan berbagai konsekuensi emosional dan tingkah laku. Sependapat dengan Ellis yang menjelaskan tentang REBT (Rational Emotif Behavior Therapy), Latipun perasaan cemas, mengganggap ada bahaya yang sedang mengancam, dan pada akhirnya akan melakukan atau mereaksi peristiwa itu tidak realistis.

Berdasarkan pengertian yang sudah dipaparkan dapat ditarik kesimpulan bahwa REBT (Rational Emotif Behavior Therapy) ialah suatu pendekatan yang mampu merubah pikiran dan tingkah laku individu yang bersifat irasional menjadi rasional.

Tujuan utama konseling dengan pendekatan Rational Emotif Behavior Therapy (REBT) adalah membantu individu menyadari bahwa mereka dapat hidup dengan lebih rasional dan lebih produktif. Menurut Gladding Rational Emotif Behavior Therapy (REBT) mendukung konseli untuk menjadi lebih toleran terhadap diri sendiri, orang lain, dan lingkungannya. Ellis dan Benard mendeskripsikan beberapa sub tujuan (REBT), tujuan tersebut yaitu : (a) memiliki minat diri (self interest); (b) memiliki minat sosial (social interest); (c) memiliki pengarahan diri (self direction); (d) toleransi (tolerance); (e) fleksibel (flexibility); (f) memiliki penerimaan (acceptance); (g) dapat menerima ketidakpastian (acceptance of uncertainty); (h) dapat menerima diri sendiri (self acceptance); (i) dapat mengambil risiko (risk taking); ( $\mathrm{j}$ ) memiliki harapan yang realisiti (realistic expectation); dan (k) memiliki toleransi terhadap frustasi yang tinggi (high frustation tolerance). Ellis menjelaskan bahwa pikiran irasional inilah yang menjadi sumber malapetaka bagi guncangnya emosi individu, sehingga menyebabkan perilaku bermasalah semua. Menurut Ellis adapun teori tradisional ABC dari konseling REBT ialah:menjelaskan bahwa REBT ialah: REBT (Rational Emotif Behavior Therapy) ialah individu yang berkeyakinan irasional, dalam menghadapi berbagai peristiwa akan mengalami hambatan emosional, seperti

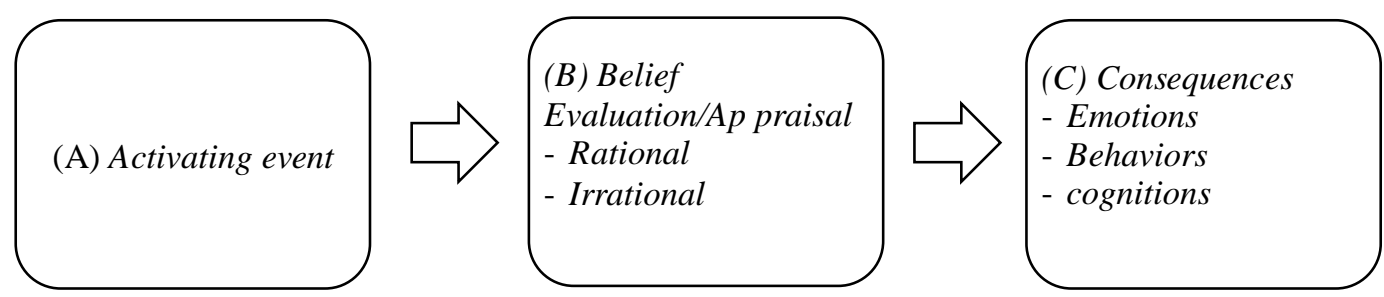

Dapat disimpulkan dari beberapa tujuan yang sudah dipaparkan bahwa tujuan dari konseling REBT (Rational Emotif Behavior Therapy) ialah menghilangkan pikiran serta tingkah laku yang irasional yang akan membuat perilaku dan tingkah lakunya bermasalah dan juga untuk mencapai perilaku dan tingkah lakunya rasional.

\section{Metode Penelitian}

Pada penelitian ini peneliti menggunakan jenis penelitiannya adalah penelitian eksperimen. Metode penelitian eksperimen merupakan metode penelitian yang digunakan untuk mencari pengaruh treatment (perlakuan) tertentu. Pada penelitian eksperimen dilakukan peneliti untuk mengetahui bagaimana pengaruh antara treatment yang diberikan guna mengurangi kecemasan peserta didik. Penelitian eksperimen yang digunakan peneliti sesuai dengan tujuan dan permasalahan yaitu Pengaruh Konseling Rational Emotif Behavior Therapy (REBT) Dalam Mengurangi Kecemasan Peserta Didik Kelas VIII SMP Gajah Mada Bandar Lampung. 


\section{Hasil dan Pembahasan}

Data yang diperoleh untuk mengetahui hasil pre-test dan post-test diperoleh dari angket yang dilakukan oleh ppeneliti mengenai kecemasan. Penelitian dilaksanakan mulai dari tanggal 28 Juli 2016 sampai dengan 28 Agustus 2016. Berikut ini adalah jadwal pelaksanaan kegiatan penelitian di SMP Gajah Mada Bandar Lampung. Berdasarkan tabel tersebut, pelaksanaan konseling Rational Emotif Behavior Therapy (REBT) dilakukan sebanyak empat kali pertemuan. Hasil konseling Rational Emotif Behavior Therapy (REBT) dievaluasi dengan melakukan pre-test sebelum diberikan treatment/perlakuan dan post-test sesudah diberikan teratment/perlakuan untuk mengetahui kecemasan peserta didik.

Pertemuan pertama

Pertemuan pertama dilaksanakan pukul 07.15 WIB di ruang osis. Kegiatan konseling kelompok ini diawali dengan mengucapkan salam kepada anggota kelompok. Pemimpin kelompok membuka pertemuan dengan perkenalan diri dengan menyebutkan nama, alamat, status, dan sebagainya. Pemimpin kelompok menjelaskan maksud, tujuan, asas-asas pelaksanaan konseling kelompok, menjelaskan tata cara pelaksanaan konseling kelompok, menyampaikan kesepakatan waktu. Anggota kelompok diberi kesempatan untuk bertanya pada pemimpin kelompok. Kemudian dilanjutkan oleh anggoa kelompok untuk memperkenalkan dirinya masing-masing.

Pertemuan kedua

Pertemuan yang kedua dilaksanakan pada 07.15 WIB dan dilaksanakan diruang osis. Pemimpin kelompok segera membuka pertemuan kedua dengan mengucapkan salam dan berdo'a, selanjutnya menjelaskan topik yang akan dibahas pada kegiatan pertemuan kedua ini yaitu merubah pemikiran irasional. Pemimpin kelompok menjelaskan tentang pemikiran irasional, memberikan penjelasan bahwa pentingnya merubah pemikiran irasional, lalu anggota kelompok diminta untuk menuliskan pikiran-pikiran irasional seperti takut ditertawakan oleh teman ketika berbicara di depan umum. Kemudian pemimpin kelompok mencoba menggali lebih mengenai permasalahan-permasalahan yang telah dituliskan oleh anggota kelompok dan mendiskusikan masalah yang telah diungkapkan oleh anggota kelompok. Pemimpin kelompok menghimbau kepada para anggota kelompok untuk memberikan pendapat dan ide. Pemimpin kelompok menginformasikan bahwa kegiatan akan segera berakhir. Kemudian menanyakan pesan dan kesan kepada anggota kelompok pada pertemuan yang kedua ini. Pertemuan diakhiri dengan do'a dan mengucapkan salam.

Pertemuan ketiga

Pertemuan ketiga dilaksanakan pukul 07.15 WIB di ruang osis. Pertemuan ini dibuka dengan mengucapkan salam dan berdo'a. Pemimpin menanyakan apa kabar dan memberi semangat pada semua anggota kelompok. Pemimpin kelompok menjelaskan topik yang akan dibahas, memberikan penjelasan tentang emosi seperti malu saat akan berbicara di depan umum, munculnya perasaan takut dan rasa tidak mampu untuk berbicara di depan umum, mendiskusikan tentang pentingnya agar dapat mengontrol emosi dan memotivasi anggota kelompok agar dapat merubah emosi yang negatif menjadi emosi yang positif. Pemimpin kelompok menyimpulkan dari kegiatan yang telah berlangsung. Pertemuan ketiga diakhiri dengan do'a dan ditutup mengucapkan salam.

Pertemuan keempat

Pertemuan keempat dilaksanakan pukul 07.15 di ruang osis. Pertemuan keempat ini dibuka dengan salam dan berdo'a. Pemimpin kelompok berterima kasih dan menanyakan kabar kepada anggota kelompok. Pemimpin kelompok memberikan semangat, lalu memberikan informasi bahwa pertemuan yang keempat ini adalah pertemuan yang terakhir dan menghimbau kepada semua anggota untuk memanfaatkan konseling kelompok ini dengan sebaik-baiknya.Pemimpin 
kelompok memberikan kesempatan kepada anggota kelompok untuk berbicara di depan umum dan pemimpin kelompok memberikan dorongan-dorongan kepada anggota agar tidak merasa gugup saat berbicara di depan umum. Saat anggota kelompok berbicara di depan umum terjadi perubahan perilaku anggota kelompok menjadi lebih baik.

Pemimpin kelompok bertanya dan mempersilahkan anggota untuk mengungkapkan apa yang dirasakan selama proses konseling kelompok berlangsung. Pemimpin kelompok menyimpulkan kegiatan yang berlangsung dan menyampaikan bahwa proses konseling hari ini akan segera berakhir. Selanjutnya, pertemuan diakhiri dengan do'a dan mengucapkan salam. Peneliti memberikan angket/kuesioner indikator kecemasan kepada 19 peserta didik yang teridentifikasi masalah penyesuaian drii sebagai pre-test untuk melihat skor awal tingkat kecemasan. Pre-test merupakana kegiatan awal yang dilakukan peneliti untuk mengetahui kondisi awal peserta didik sebelum diberikan Rational Emotif Behavior Therapy. Pretest dilakukan dengan tujuan untuk mengetahui gambaran kondisi awal kecemasan peserta didik di SMP Gajah Mada Bandar Lampung. Berikut dijelaskan hasil atau kondisi pretest gambaran kondisi awal kecemasan peserta didik

Berdasarkan hasil analisis data yang telah dianalisis, terlihat terdapat adanya penurunan tingkat kecemasan di SMP Gajah Mada Bandar Lampung. Dapat dilihat dari hasil penelitian setelah dan sebelum diberikannya layanan konseling Rational Emotif Behaviooral Therapy (REBT). Selain itu dilakukan uji hipotesis menggunakan uji t paired sample $t$ - $t$ dan diketahui $\mathrm{t}$ adalah 24.044 mean 1873.6, 95\% confidence interval of the difference, lower $=17.09965$ dan upper $=20.37403$. Kemudian $t_{\text {hitung }}$ dibandingkan dengan $t_{\text {tabel }} \mathrm{df}=18$, dengan ketentuan $t_{\text {hitung }}$

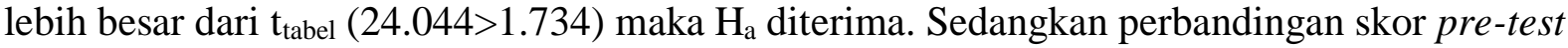
55,7 post-test 33,7 yang berarti terjadi penurunan sebesar 18,7. Mengurangi kecemasan pada peserta didik melalui konseling kelompok menggunakan pendekatan Rational Emotif Behavioral Therapy (REBT) dilakukan melalui beberapa tahap konseling dengan empat kali pertemuan. Menurut penelitian Adik Hermawan dalam skripsi yang berjudul Konseling Rational Emotif Behavior Therapy Berbasis Islam yang direncanakan untuk pemberian treatment akan dilaksanakan selama 4 (empat) kali pertemuan dimana setiap pertemuan dilaksanakan dua kali dalam satu minggu dan dua kali pertemuan digunakan untuk melakukan pre-test dan pos-tes.

Dalam penelitian ini diterapkan layanan konseling rational emotif behavioral therapy (REBT) Latipun menjelaskan bahwa REBT ialah individu yang berkeyakinan irasional, dalam menghadapi berbagai peristiwa akan mengalami hambatan emosional, seperti perasaan cemas, mengganggap ada bahaya yang sedang mengancam, dan pada akhirnya akan melakukan atau mereaksi peristiwa itu tidak realistis. Peneliti menggunakan konseling rational emotof behavioral therapy (REBT) bertujuan konseling dengan pendekatan Rational Emotif Behavior Therapy (REBT) adalah membantu individu menyadari bahwa mereka dapat hidup dengan lebih rasional dan lebih produktif. Calhoun dan Acocella menjelaskan kecemasan adalah perasaan ketakutan (baik realistis maupun tidak realistis) yang disertai dengan keadaan peningkatan reaksi kejiwaan.

Setelah diberikannya perlakuan sebanyak empat kali pertemuan peserta didik dapat memahami dan mengerti topik yang dibahas. Untuk itu peserta didik sudah dapat mengerti dengan tindakan yang dilakukan untuk terus menurunkan tingkat kecemasannya. Secara indikator terjadi penurunan tingkat kecemasan setelah diadakan konseling rational emotif behavioral therpay. Berikut tiga komponen kecemasan, yaitu:

a. Fisik

Berdasarkan hasil penyebaran angket yang terjadi pada indikator fisik terjadi penurunan setelah diadakan konseling rational emotif behavior therapy, dapat dilihat dari nilai uji ttest sample berpasangan (Paired samples t-test) 2,81288 menurun menjadi 1,69450. 
Peserta didik mampu berbicara di depan umum tanpa adanya perasaan jantung yang berdebar-debar atau suara yang bergetar.

b. Mental

Berdasarkan hasil penyebaran angket yang terjadi pada indikator mental terjadi penurunan setelah diadakan konseling rational emotif behavior therapy, dapat dilihat dari nilai uji t- test sample berpasangan (Paired samples t-test) 17,9474 menurun menjadi 13,9474. Hal ini dapat terlihat ketika peserta didik berbicara di depan umum tidak mengulang perkataan atau lupa apa yang akan dibicarakan selanjutnya.

c. Emosional

Berdasarkan hasil penyebaran angket yang terjadi pada indikator emosional terjadi penurunan setelah diadakan konseling rational emotif behavior therapy, dapat dilihat dari nilai uji t- test sample berpasangan (Paired samples t-test) 15,3684 menurun menjadi 8,7368. Penurunan pada indikator emosional mengalami perubahan yang signifikan, sehingga apabila tidak terjadinya penurunan seseorang yang mengalami kecemasan akan terganggu pada proses belajar mengajar hal tersebut senada dengan pendapat Sieber yang menyatakan bahwa kecemasan yang berlebihan akan menjadi sesuatu yang merugikan apabila berada pada batas di luar kewajaran, sehingga individu yang mengalami kecemasan dipengaruhi oleh beberapa hal, diantaranya karena adanya pengalaman negatif seperti kekhawatiran akan adanya kegagalan.

\section{Simpulan dan Saran}

Berdasarkan hasil penelitian dan pembahasan tentang pengaruh Rational Emotif Behavioral Therapy (REBT) dalam Mengurangi Kecemasan Peserta Didik SMP Gajah Mada Bandar Lampung dapat disimpulkan bahwa telah terjadi penurunan tingkat kecemasan pada peserta didik setelah dilakukan Rational Emotif Behavioral Therapy (REBT). Hal ini terbukti dari hasil pre-test dan post-test dilakukan, hasil perhitungan rata-rata skor kecemasan sebelum mean pretest mengikuti konseling Emotif Behavioral Therapy (REBT) adalah 55,7 dan setelah mean pre-test mengikuti konseling Emotif Behavioral Therapy (REBT) adalah 33,7. Dari hasil uji t

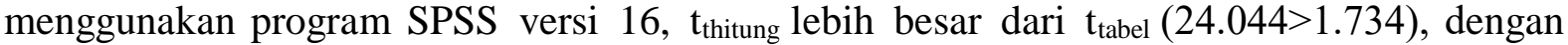
demikian kecemasan peserta didik mengalami perubahan setelah diberikan layanan Rational Emotif Behavior Therapy (REBT).

Jadi ini menunjukkan $\mathrm{H}_{0}$ ditolak $\mathrm{H}_{a}$ diterima, maka disimpulkan bahwa terdapat pengaruh Rational Emotif Behavior Therapy (REBT) dalam mengurangi kecemasan peserta didik di SMP Gajah Mada Bandar Lampung.Secara keseluruhan penelitian ini menghasilkan kesimpulan bahwa Rational Emotif Behavior Therapy (REBT) memiliki pengaruh dalam mengurangi kecemasan peserta didik yang ditandai adanya pengurangan dari kecemasan yang dialami peserta didik. Hal ini dapat dilihat dari perbedaan dan perbandingan antara hasil pretest dan post- test.

\section{Daftar Pustaka}

Albert Ellis 2014, The Empirical Status of Rational Emotif Behavior Therapy (Rebt) Theory \& Practice Albert Ellis Institute New York, Tersedia Jurnal (http://albertellis.orgpdf_filesThe-Empirical-Status-of-Rational-Emotive-BehaviorTheory-and-Therapy.pdf diakses pada pukul 09.30 WIB 31 Januari 2016.

Al Qur'an dan Terjemahnya (revisi terbaru D.A RI, Semarang, CV. Asy Syifa) QS. Al-Fajr ayat 27:30.

Anwar Indi Dwisty Astrid, Hubungan Self Efficacy Dengan Kecemasan Berbicara Di Depan Umum Pada Mahasiswa Psikologi Universitas Sumatera Utara, Tersedia Skripsi 
(http://repository.usu.ac.id/bitstream/123456789/14504/1/10E00001.pdf diakses pada tanggal 25 Februari Pukul 20.39 WIB.

Aqib Zainal, Konseling Kesehatan Mental, (Bandung: CV Yrama Widya, 2013).

Dewa Ketut Sukardi, Pengantar Pelaksanaan Program Bimbingan dan Konseling di Sekolah, (Jakarta, PT. Rineka Cipta, 2008).

Fahmi Agustiana Sixtine, Tingkat Kecemasan dan Depresi Pada Penderita Geographic Tongue (Studi Epidemiologi Pada Mahasiswa Fakultas Kedokteran Gigi Universitas Jember), Tersedia Skripsi(httprepository.unej.ac.idbitstreamhandle12345678961579Sixtine\%20Agust ina\%20Fahmi\%20\%20111610101060.pdfsequence=1.pdf diakses pada pukul 09.23 WIB 23 Maret 2016.

Friedman.S. Howard \& Schustack.W.Miriam, Kepribadian Teori Klasik dan Riset Modern, (Jakarta: Erlangga, 2008).

Gantina Komalasari \& dkk, Teori dan Teknik Konseling, (Jakarta Barat, PT Indeks, 2011).

Hadi Sutrisno, Metodologi Research, (Yogyakarta, Andi Offset, 1988).

Haryanthi Putu Suta Luh \& Tresniasari Nia, Efektifitas Metode Terapi Ego State Dalam Mengatasi Kecemasan Di Depan Publik Pada Mahasiswa Fakultas Psikologi UIN Syarif Hidayatullah Jakarta (Online) Jurnal, (http://journal.unair.ac.idfilerPDFartikel\%204-14-1.pdf diakses pada tanggal26 Februari 2016 pukul 12.32 WIB.

Jayanti Tri, 2012, Mengurangi Perilaku Siswa tidak Tegas Melalui Pendekatan REBT dengan Teknik Assertive Training Univ. Negeri Semarang, (Online) Jurnal (http://journal.unnes.ac.idartikel_sjujbk309358.pdf diakses pada pukul 19.20 WIB 28 Januari 2016.

Kartono Kartini, Kamus Lengkap Psikologi, (Jakarta: Raja Grafindo Persada, 2004)

Khairani Makmun, Psikologi Konseling, (Yogyakarta, CV. Aswaja Persindo, 2014).

Mappiare Andi, Pengantar Konseling dan Psikoterapi edisi Kedua, (Jakarta; PT.Rahja Grafindo Persada, 2011).

Margono.S, Metodologi Penelitian Pendidikan, (Jakarta: PT Rineka Cipta, 2010).

Muhibbin Syah, Psikologi Belajar, (Jakarta: Rajawali Pers, 2012).

Nani Wulandari, Guru BK SMP Gajah Mada Bandar Lampung.

Nevid.S. Jefrfrey, dkk, Psikologi Abnormal, (Jakarta: Erlangga, 2003).

Prambudhi Ambar Yuliastri dkk, 2015, Efektivitas Group Cognitive Behavior Therapy (GCBT) dalam Menurunkan Kecemasan Menghadapi Pelaku Bullying ditinjau dari Harga Diri Pada Korban Bullying Universitas 17 Agustus, (Online) Jurnal (htt://pejournal.umm.ac.idindex.phpjiptarticleviewFile21242274.pdf diakses 19.04 WIB 29 Januari 2016.

Puspito Triyoso Adi, Layanan Konseling Kelompok Dengan Pendekatan Rasional Emotiv Behavior Therapy (REBT) Untuk Pengembangan Kemampuan Berfikir Positif Pada Siswa Kelas VIII mtsN Sale Rembang Tahun Ajaran 2015/2016, Tersedia Skripsi, diakses pada 20.22 WIB 31 Maret 2016. 
Safaria Triantoro \& Saputra.E.Nofrans, Manajemen Emosi Sebuah Panduan Cerdas Bagaimana Mengelola Emosi Positif dalam Hidup Anda, (Jakarta: Bumi Aksara,2012).

Setianingrum Ari Agustina, \& dkk, 2013, Upaya Mengurangi Kecemasan Berbicara di Depan Umum Menggunakan Teknik Relaksasi Pada Mahasiswa FKIP Unila, Tersedia Jurnal, (http://jurnal.fkip.unila.ac.id/index.php/ALIB/article/viewFile/2796/1875.pdf diakses pada 12.11WIB 20 Juli 2015).

Slameto, Belajar dan Faktor-faktor yang Mempengaruhinya, (Jakarta, PT Rineka Cipta, 1995).

Mardia Bin Smith, Pengaruh Layanan Konseling Kelompok Terhadap Disiplin Belajar Siswa Di Sma Negeri 1 Atinggola Kabupaten Gorontalo Utara, Tersedia Jurnal, (http://repository.ung.ac.idgetsimlit_res1212Pengaruh-Layanan-KonselingKelompok-terhadap-Disiplin-Belajar-Siswa-di-SMA-Negeri-1-AtinggolaKabupaten-Gorontalo-Utara.pdf diakses pada 20.24 WIB 31 Maret 2016.

Sugiyono, Metode Penelitian Kuantitatif Kualitatif dan R\&D, (Bandung: Alfabeta CV, 2011).

Suyadi, Buku Pegangan Bimbingan Konseling untuk Paud, (Jogjakarta, Diva Press, 2009). http://wirnursing.blogspot.co.id/2009/11/ansietas-ataukecemasan.html?m=1,diakses pada Rabu, 25 Mei 2016 jam 12.40 WIB. 
